\title{
The Effectiveness of the Setting of Volleyball Training Guide Model to Increase the Setting Skill
}

\author{
Khurotul Aini \\ Sport Education \\ State University of Jakarta \\ Islamic University of 45 Bekasi \\ Jakarta, Indonesia \\ khurotulaini_por1623@mahasis \\ wa.unj.ac.id \\ ME Winarno \\ Faculty of Sport Science \\ State University of Malang \\ Malang, Indonesia \\ winarno_eko@yahoo.com
}

\author{
Moch. Asmawi \\ Faculty of Sport Science State \\ University of Jakarta \\ Jakarta, Indonesia \\ asmawi.moch@yahoo.co.id
}

\author{
James Tangkudung \\ Faculty of Sport Science \\ State University of Jakarta \\ Jakarta, Indonesia \\ james24061952@gmail.com
}

\author{
Ramdan Pelana \\ Faculty of Sport Science \\ State University of Jakarta \\ Jakarta, Indonesia \\ ramdanpelana@yahoo.com
}

\author{
Achmad Sofyan Hanif \\ Faculty of Sport Science \\ State University of Jakarta \\ Jakarta, Indonesia \\ Sofyan_dean@yahoo.com
}

\author{
Firmansyah Dlis \\ Faculty of Sport Science \\ State University of Jakarta \\ Jakarta, Indonesia \\ firmansyahdlis@yahoo.com
}

\begin{abstract}
Development of science and technology an important to improving of human resources, especially in the issue of education. The use of media in learning and training activities greatly helps the process of delivering material effectively and efficiently. The use of appropriate media will help encouraging motivation, creativity, and enthusiasm of students or athletes in participating in exercises activities . The purpose of this study is to find out whether the guidebook on volleyball passing training model for volleyball extracurricular participants at the junior high school level is effectively used as a medium to improve volleyball passing skill at junior high school age. The numbers of research subjects are 60 junior high school students in Makassar, South Sulawesi, selected by using purposive sampling. This research uses the Research and Development (R\&D) method from Borg and Gall. Based on the results of the pretest and posttest test to the research subjects obtained significant results on improving passing skills on volleyball. So it can be concluded that the manual about the volleyball passing training model for junior volleyball extracurricular participants is effectively used to improve the results of volleyball passing skills.
\end{abstract}

Keywords: exercise, setting, games

\section{INTRODUCTION}

The need for technological development at this time is the latest innovation to achieve the latest breakthroughs. The innovativeness of course cannot be separated from the stages of learning cognition that have been taken by students. This is done so that the new breakthroughs created do not neglect the main actors in the learning process. One form of communication which can be done by trainers, coaches and teachers can be through media.

Media is one source of learning that is understood as a device, material, or arrangement, where students can interact with the surrounding environment with the aim of facilitating students to improve performance[1]. The media is a form of a communication channel to convey messages from the sender of information to the recipient of information. In a study or exercise, it also needs the right media to deliver material effectively and efficiently. Educational or learning media are said to be media if they are used to channel or convey messages with educational goals. In general, educational media have the following uses: 1) Clarify the presentation of the message, so that it is not too verbal or mere verbal; 2) Overcome the limitations of space, time and sense, and 3) The use of varied and appropriate educational media can overcome the passivity of students [2].

Therefore, teachers, trainers and coaches are expected to be able to present media in a form which is more interesting, varied and able to improve students' activity in learning activities. In learning activities, a good system design is needed to design, analyze and implement an instruction carried out by a trainer, teacher or coach to students as participants. This is in line with the opinion which states that instructional design or instructional systems design conceptualizing the preparatory process of instruction is the most representative field in educational technology, Gustafson in [3]. The use of the study guide is a form of instructional design which is used to design approaches appropriate for students, to design, to develop the material, and to be used as further evaluation material. In addition, using media will involve students or athletes to share ideas, understand other people's reactions, sharpen thinking and deepen understanding [4]. Research and development are needed to develop learning media. In the educational field, the main purpose of research and development is not to formulate or test theories, but to develop effective products for use in schools [5]. An effective product is a product which is able to overcome the gaps between expectation and reality that can be generated in the form of hardware, software and has certain characteristics which meet the current needs. Learning media strongly supports activities in the field of sports, in which sports play an active role 
in increasing student activity. The results of the study prove the statement stating that Studies have shown that children who participate in organized sports are significantly more active than those who do not [6]. In addition, sports can overcome negative problems such as anxiety, stress and depression in athletes [7].

The use of visual media is also needed in sports volleyball. The importance of visual information in the learning process is well known. Consider that, on average, people learn $1 \%$ through what they like, $1.5 \%$ through what they touch, 3.5\% through what they smell, $11 \%$ through what they hear, but $83 \%$ through what what they see. The study also found that individuals retained $10 \%$ of what they wrote, $20 \%$ of what they heard, $30 \%$ of what they saw, $50 \%$ of what they saw and heard, and $70 \%$ of what they discussed [8] It is well known that volleyball is a popular sport. This is because there have been many studies stating that volleyball is a sport which can improve total body performance [9]. Athletes need to develop basic movement skills to develop special skills so that they are able to excel. Volleyball is a sport which depends a lot on internal and external factors. It is in line with the opinion stating that winning a volleyball match is dependent on the personal factors of players' motor skills, trainers' coaching skills, and on the intellectual factors of match analysis and strategy development, Mottley in [10]. This means that all internal and external aspects are closely related to the success of a sport. One of the most successful forms of volleyball training is the mastery of basic techniques. The basic techniques in volleyball are serving, passing, setting, attacking, blocking, and serving receive. To stimulate children to master basic techniques, it is done with an interesting or illustrated guidebook [11].

By all means, coaches need to teach athletes the basic skills. One of the basic techniques which need to be done is to train the passing on each student, meaning that it is not only for the tosser. This is in line with the opinion which states that when a child's ability to set the ball allows your team to create a scoring opportunity out of a broken play [12]. Hence, each student will be able to get points from the setting skills they have and does not depend on the setters. To carry out varied passing exercises, it is necessary to do research and development on volleyball, especially passing. Research and development (R\&D) is a process for developing and validating a product. The steps of this process are called cycles which consist of studying research findings related to the product, developing the product based on these findings, testing it in the place of the research subject, revising it to correct the deficiencies found at the proposed testing stage. In a more rigorous $\mathrm{R} \& \mathrm{D}$ program, this cycle is repeated until it shows the value that the product meets the objectives set.[13]. Research and development emphasizes the process used to develop and justify the results of products which are developed to the experts and have sequential steps.

Participants in this study are volleyball extracurricular participants in a junior high school classified as adolescence. During this period, the recognizable period of physical activity decline [14]. The statement explains that efforts are needed to increase physical activity such as exercise in extracurricular activities which are carried out regularly and in an organized manner. This is in line with the opinion which states that exercise is described as planned, structured, repetitive, and purposive with the goal of physical improvement [15]. Therefore, through proper exercise, an increase in physical activity will be achieved properly. Exercise is not only done prior to the championship or competition, but it needs to be done in a long-term period.

This is in line with the opinion which states that players that acquired higher amount of game skills then possess an advantage [16] This means that mastering a number of basic skills as much as possible will benefit athletes to properly complete a task either independently or in groups or teams in certain sports. It should also be supported by a good training program and be carried out by professional trainers who already have good training programs. The results of the study stated that inadequate or unsuitable training programs would reduce the physical condition and skills of the students [17].

Based on the results of a needs analysis conducted for 20 extracurricular participants and interviews with 2 volleyball trainers, it is found that (1) The experience as a volleyball player is around 14-15 years, but the experience as a trainer for volleyball is only 3-4 years; (2) Trainers got the experience when they were players and college students; (3) The trainer applies the upper passing variation exercises such as in pairs and independent drills; (4) As much as $86.95 \%$ of athletes need variations in the exercise to help reducing boredom during the training; (5) Athletes need guidebooks to help the training process and (6) Trainers need reference material to train volleyball passing.

\section{METHOD}

\section{A. Research Method}

\section{1) Method}

The method used in this study uses the Borg and Gall method using nine steps [18], basically comprise two main objectives: (1) developing the product and (2) testing the effectiveness of the product in achieving the goal. The first objective is called validation. Thus, the concept of research and development is more properly defined as a development effort coupled with validation.

\section{2) Process}

The implementation of this research uses Borg \& Gall's (1983) research and development process through nine processes, namely: (1) Research and Information Collection, (2) Planning, (3) Preliminary Development, (4) Preliminary Field Testing, (5 ) Main Product Revisions, (6) Main Field Testing, (7) Operational Product Revisions, (8) Operational Field Trials and (9) Final Product Revisions [18]. The following is a description of the research process carried out by researchers in table 1 .

\section{3) Participants}

The subjects of the study were extracurricular participants $(n=60)$ of volleyball in the junior high schools, namely State Junior High Schools 3, 13, 24 and 27 Makassar City with characteristics aged 13-16 years old. The sampling technique used was purposive sampling. This research was conducted from September 2017 to October 2018. A trial was conducted on volleyball experts, games, media and training to perfect the guidebook product for volleyball. 
TABLE II. RESEARCH DESIGN IN THE EFFECTIVENESS TESTING OF THE GUIDEBOOK

TABLE I. THE PROCESS OF RESEARCH

\begin{tabular}{|c|c|c|}
\hline \multicolumn{3}{|r|}{ Process of Research } \\
\hline No & $\begin{array}{l}\text { The Research } \\
\text { Procedures }\end{array}$ & Descriptions of Process \\
\hline 1 & $\begin{array}{l}\text { Research and } \\
\text { Information } \\
\text { Collection }\end{array}$ & $\begin{array}{l}\text { Researchers conducted a needs analysis of } 20 \\
\text { volleyball extracurricular participants and } \\
\text { interviews with } 2 \text { volleyball trainers at junior } \\
\text { high schools in Makassar. }\end{array}$ \\
\hline 2 & Planning & $\begin{array}{l}\text { Researchers planned a draft in the form of } \\
\text { identification of skills, formulation of } \\
\text { objectives, determination of tests, expert } \\
\text { testing, small scale trial and large group trial. }\end{array}$ \\
\hline 3 & $\begin{array}{l}\text { Development of } \\
\text { the Preliminary }\end{array}$ & $\begin{array}{l}\text { The researchers developed variations of the } \\
\text { exercise model, which were compiled in the } \\
\text { exercise guidebook initial draft. }\end{array}$ \\
\hline 4 & $\begin{array}{l}\text { Preliminary Field } \\
\text { Testing }\end{array}$ & $\begin{array}{l}\text { Conducted initial field trial or small group }(n= \\
\text { 12) at } 3 \text { junior high schools in Makassar City. }\end{array}$ \\
\hline 5 & $\begin{array}{l}\text { Main Product } \\
\text { Revision }\end{array}$ & $\begin{array}{l}\text { After conducting an initial trial or small group } \\
\text { trial, records and things which need to be } \\
\text { considered in the field implementation will be } \\
\text { obtained, so the researchers need to revise the } \\
\text { product. }\end{array}$ \\
\hline 6 & $\begin{array}{l}\text { Main } \\
\text { Testing }\end{array}$ & $\begin{array}{l}\text { Carried out field trial or large group trial }(\mathrm{n}= \\
30) \text {. }\end{array}$ \\
\hline 7 & $\begin{array}{l}\text { Operational } \\
\text { Product Revision }\end{array}$ & $\begin{array}{l}\text { Conducted product revisions, based on large } \\
\text { group trial activities. }\end{array}$ \\
\hline 8 & $\begin{array}{l}\text { Operational Field } \\
\text { Testing }\end{array}$ & $\begin{array}{l}\text { The researchers conducted the main product test } \\
\text { or product effectiveness test }(n=60) \text {. }\end{array}$ \\
\hline 9 & $\begin{array}{l}\text { Final Product } \\
\text { Revision }\end{array}$ & $\begin{array}{l}\text { Performed product revisions } \\
\text { operational field testing activities. }\end{array}$ \\
\hline
\end{tabular}

\section{B. Data Analysis}

The Data analysis form of descriptive qualitative percentage analysis as follows.

\section{1) The formula for processing data per subject.}

$$
\mathrm{P}=\frac{x}{X i} \mathrm{x} 100 \%
$$

Information:

$\mathrm{P}$ : Percentage of subject evaluation results

$X$ : Number of answer scores by the subject

$\mathrm{X}_{\mathrm{i}}$ : The maximum number of answers in the aspect of assessment by the subject

\section{2) The formula for processing data as a whole subject:}

$$
\mathrm{P}=\frac{\Sigma X}{\Sigma X i} \mathrm{x} 100 \%
$$

\section{Information:}

$\mathrm{P}$

$\Sigma X$

$\sum \mathrm{Xi}$

To test the effectiveness of the guidebook, the one-group pretest-posttest design which is pre-experimental research design was used as shown in table 2 below:

\begin{tabular}{|c|c|c|c|}
\hline \multicolumn{4}{|c|}{ Research Design in the Effectiveness Testing of the Guidebook } \\
\hline Subject & Pre-Test & Treatment & Post-Test \\
\hline $\mathrm{R}$ & $\mathrm{O}_{1}$ & $\mathrm{X}$ & $\mathrm{O}_{2}$ \\
\hline
\end{tabular}

The steps in this trial include; (1) forming a group of research subjects; (2) conducting a pre-test $\left(\mathrm{O}_{1}\right) ;(3)$ trying a product that has been developed; (4) carrying out post-test $\left(\mathrm{O}_{2}\right)$; (5) looking for pre-test and post-test average scores and comparing them; (6) finding the difference between the two averages through the T-Test using the SPSS 21 application program.

\section{RESUlt AND DisCUSSION}

\section{A. Product Development Results}

Research and development conducted by the researchers resulted in the findings summarized in table 3 :

TABLE III. THE RESUlts OF RESEARCH AND DEVELOPMENT

\begin{tabular}{|c|c|c|}
\hline $\begin{array}{l}\mathbf{N} \\
\mathbf{0}\end{array}$ & $\begin{array}{c}\text { The } \\
\text { Research } \\
\text { Procedures }\end{array}$ & Descriptions \\
\hline 1 & $\begin{array}{l}\text { Research and } \\
\text { Information } \\
\text { Collecting }\end{array}$ & $\begin{array}{l}\text { 1. Results of interviews of trainers }(\mathrm{n}=2) \text { and } \\
\text { athletes, obtained results that: } \\
\text { a. The trainer has not yet applied variations of } \\
\text { the upper passing exercises to the maximum. } \\
\text { b. The trainer is still having trouble when } \\
\text { training over passes. } \\
\text { c. Athletes need training variations to reduce } \\
\text { boredom during training. } \\
\text { d. Coaches and athletes need reference material } \\
\text { to practice volleyball passing. } \\
\text { 2. Results of questionnaire distribution to volleyball } \\
\text { extracurricular participants }(\mathrm{n}=20) \text { with a total } \\
\text { of } 17 \text { questions. } \\
\text { 3. Based on the results of the needs analysis, } \\
80.90 \% \text { of athletes need a passing guidebook on } \\
\text { volleyball. }\end{array}$ \\
\hline 2 & Planning & $\begin{array}{l}\text { The researchers plan the guidebook draft based on: } \\
\text { 1. Identification of the skills which are difficult } \\
\text { for athletes to do, namely passing. } \\
\text { 2. The purpose of the preparation of the passing } \\
\text { exercise guidebook is to help athletes and } \\
\text { trainers to more easily learn training materials, } \\
\text { especially passing more easily and efficiently. } \\
\text { 3. Testing the effectiveness of the manual is by } \\
\text { distributing questionnaires to extracurricular } \\
\text { participants about the ease of use. } \\
\text { 4. Trial } \\
\text { a. Expert test results } n=(3) \text { about the feasibility } \\
\text { of the product to be tested with an instrument } \\
\text { of } 100 \text { questions: } \\
\text { Volleyball expert as much as } 75,6 \%= \\
\text { feasible } \\
\text { - Games expert as much as } 77 \%=\text { feasible } \\
\text { Training expert as much as } \mathbf{8 5 \% = h i g h l y ~} \\
\text { feasible } \\
\text { Media expert as much as } \mathbf{8 0 \%}=\text { feasible } \\
\text { Small-Group Trials }\end{array}$ \\
\hline
\end{tabular}

$$
\text { The Results of Research and Development }
$$


Description:

Group $1=$

Group 2 =

$\mathrm{n}=$ Number of test

$\mathrm{L}_{\mathrm{o}}=\mathrm{L}$-count value

$\mathrm{L}_{\mathrm{t}}=\mathrm{L}$-table value

$\alpha=0.05$

The results of normality test, as shown in table 1, Lo values obtained for all pretest and posttest data for basic volleyball passing skills on are smaller than Lt at the real level $\alpha=0.05$. Thus it can be concluded that all the pretest and posttest data of volleyball passing skills are from normally distributed populations.

Before conducting further data analysis, it is necessary to test the effectiveness of the implementation of the volleyball guidebook for junior high school volleyball extracurricular participants using the paired sample t-test with the application of SPSS version 21 with the summary in table 5 as follows:

TABLE V. PAIRED SAMPLES ResUlts FOR PASSING ABILITy TeSTS

\begin{tabular}{|c|c|c|c|c|}
\hline \multicolumn{3}{|c|}{ t } & df & Sig. (2-tailed) \\
\hline Pair & $\begin{array}{c}\text { Pre-test - } \\
\text { Post- test }\end{array}$ & -73.900 & 29 & .000 \\
\hline
\end{tabular}

The basis of decision making: If the Sig. (2-tailed) $<0.05$, there is a significant difference between the results of the exercise on the pre-test and post-test data. If the Sig. (2-tailed)> 0.05, there is no significant difference between the results of the exercise on the pre-test and post-test data. So can be concluded that there is a significant difference in the results of passing training on volleyball in the pretest and posttest data. Thus it can be stated that the guidebook on volleyball passing training models for junior high school volleyball extracurricular participants is effectively used to improve the results of volleyball passing skills.

\section{CONCLUSION}

After data analysis and discussion, it can be concluded that the hypothesis that the passing exercise guidebook model for extracurricular participants is proven to be able to help trainers and athletes to improve their volleyball passing skills effectively and efficiently. Thus the use of the volleyball passing exercise guidebook model is effective for use.

\section{REFERENCES} design". The T-test was used to the effectiveness of the application of the guidebook on passing model. Before conducting data analysis, it is necessary to test the normality of the results of the pre-test and post-test of volleyball passing using the Lilliefors [19] at the real level $\alpha=0.05$. The following is a summary of the results of normality test calculations shown in table 4 below:

TABLE IV. SUMMARY OF TEST RESUlTS FOR NORMALITY IN PRETEST AND POSTTEST DATA OF VOLLEYBALL PASSING SKILLS

\begin{tabular}{|c|c|c|c|c|}
\hline Group & $\boldsymbol{n}$ & $\boldsymbol{L}_{\boldsymbol{o}}$ & $\boldsymbol{L}_{\boldsymbol{t}}$ & Conclusion \\
\hline 1 & 30 & 0.016 & 0.114 & Normal \\
\hline 2 & 30 & 0.005 & 0.114 & Normal \\
\hline
\end{tabular}

[1] M. Januszewski \& Molenda, Educational Technology. New York: Routledge, 2008.

[2] D. W. Dwiyogo, Aplikasi Teknologi Pembelajaran Media Pembelajaran Penjas \& Olahraga. Malang: Fakultas Ilmu Pendiidkan Universitas Negeri Malang, 2008.

[3] C. Lim, S. Choi, and M. Hong, “A Developmental Study of Instructional Systems Design Model for Primary School Teacher," $J$. Educ. Technol., vol. 26, no. 4, pp. 121-147, 2017.

[4] V. Trajkovik, T. Malinovski, T. Vasileva-Stojanovska, and M. Vasileva, "Traditional games in elementary school: Relationships of student's personality traits, motivation and experience with learning 
outcomes," PLoS One, vol. 13, no. 8, pp. 1-15, 2018.

[5] Emzir, penelitian pendidikan: kuantitatif \& kualitatif. Jakarta: Raja Grafindo Persada, 2012.

[6] K. Ridley, S. Zabeen, and B. K. Lunnay, "Children 's physical activity levels during organised sports practices," J. Sci. Med. Sport, pp. 10-14, 2018.

[7] C. Taskin, "Examination of Academic Achievement in Early Adolescence: A Comparison for Adolesence with Visual Impairments Doing Sport or Not Doing Sport,” J. Educ. Learn., vol. 5, no. 2, p. 265, 2016.

[8] Simatos, Technology and Education. Athens: Patakis Press, 2000.

[9] A. Pereira, A. M. Costa, P. Santos, T. Figueiredo, and P. V. João, "Training strategy of explosive strength in young female volleyball players," Med., vol. 51, no. 2, pp. 126-131, 2015.

[10] K. Lin, "Applying game theory to volleyball strategy," Int. J. Perform. Anal. Sport, vol. 14, no. 3, pp. 761-774, 2014.

[11] A. Yilmaz and Ş. Pala, "Sports in children's picture books," Univers. J. Educ. Res., vol. 7, no. 3, pp. 824-838, 2019.

[12] G. Bach, Choaching volleyball for Dummies. Indiana: Wiley
Publishing, 2009.

[13] M. D. Gall, J. P.Gall, and W. R. Borg, "Meredith D. Gall, Walter R. Borg, Joyce P. Gall - Educational Research_An Introduction (7th Edition)-Allyn \& Bacon (2003).” 2003.

[14] R. Sutherland et al., “" Physical Activity 4 Everyone ' school-based intervention to prevent decline in adolescent physical activity levels : 12 month ( mid-intervention ) report on a cluster randomised trial," pp. 488-495, 2016.

[15] J. W. Ball, M. R. Bice, and T. Parry, "Adults ' Motivation for Physical Activity: Differentiating Motives for Exercise, Sport, and Recreation," pp. 130-142, 2014.

[16] A. U. Carolinae, F. Of, P. Education, and J. Buchtel, "Specialized training of children and youngsters in selected sports games," vol. 49, pp. 17-36, 2013.

[17] R. J. Shephard, "Physical Activity and Child Health," Sport. Med. An Int. J. Appl. Med. Sci. Sport Exerc., vol. 1, no. 3, pp. 205-233, 1984.

[18] W. R. Borg and M. D. Gall, "Educational Research: An Introduction, 4th Edition," in 4, New York: Longman Inc, 1983.

[19] Sudjana, Metoda Statistika. Bandung: Tarsito, 2002. 